\title{
Development of health-based exposure limits for radiofrequency radiation from wireless devices using a benchmark dose approach
}

\author{
Uloma Igara Uche ${ }^{*}$ and Olga V. Naidenko
}

\begin{abstract}
Background: Epidemiological studies and research on laboratory animals link radiofrequency radiation (RFR) with impacts on the heart, brain, and other organs. Data from the large-scale animal studies conducted by the U.S. National Toxicology Program (NTP) and the Ramazzini Institute support the need for updated health-based guidelines for general population RFR exposure.

Objectives: The development of RFR exposure limits expressed in whole-body Specific Absorption Rate (SAR), a metric of RFR energy absorbed by biological tissues.

Methods: Using frequentist and Bayesian averaging modeling of non-neoplastic lesion incidence data from the NTP study, we calculated the benchmark doses (BMD) that elicited a $10 \%$ response above background $\left(\mathrm{BMD}_{10}\right)$ and the lower confidence limits on the $\mathrm{BMD}$ at $10 \%$ extra risk $\left(\mathrm{BMDL}_{10}\right)$. Incidence data for individual neoplasms and combined tumor incidence were modeled for $5 \%$ and $10 \%$ response above background.

Results: Cardiomyopathy and increased risk of neoplasms in male rats were the most sensitive health outcomes following RFR exposures at $900 \mathrm{MHz}$ frequency with Code Division Multiple Access (CDMA) and Global System for Mobile Communications (GSM) modulations. $\mathrm{BMDL}_{10}$ for all sites cardiomyopathy in male rats following 19 weeks of exposure, calculated with Bayesian model averaging, corresponded to $0.27-0.42 \mathrm{~W} / \mathrm{kg}$ whole-body SAR for CDMA and $0.20-0.29 \mathrm{~W} / \mathrm{kg}$ for GSM modulation. $\mathrm{BMDL}_{10}$ for right ventricle cardiomyopathy in female rats following 2 years of exposure corresponded to 2.7-5.16 W/kg whole-body SAR for CDMA and 1.91-2.18 W/kg for GSM modulation. For multi-site tumor modeling using the multistage cancer model with a $5 \%$ extra risk, $\mathrm{BMDL}_{5}$ in male rats corresponded to $0.31 \mathrm{~W} / \mathrm{kg}$ for CDMA and $0.21 \mathrm{~W} / \mathrm{kg}$ for GSM modulation.
\end{abstract}

Conclusion: $\mathrm{BMDL}_{10}$ range of $0.2-0.4 \mathrm{~W} / \mathrm{kg}$ for all sites cardiomyopathy in male rats was selected as a point of departure. Applying two ten-fold safety factors for interspecies and intraspecies variability, we derived a whole-body SAR limit of 2 to $4 \mathrm{~mW} / \mathrm{kg}$, an exposure level that is 20-40-fold lower than the legally permissible level of $0.08 \mathrm{~W} / \mathrm{kg}$ for whole-body SAR under the current U.S. regulations. Use of an additional ten-fold children's health safety factor points to a whole-body SAR limit of $0.2-0.4 \mathrm{~mW} / \mathrm{kg}$ for young children.

Keywords: Radiofrequency radiation, Specific Absorption Rate, SAR, Exposure guidelines, Benchmark modeling

*Correspondence: uloma.uche@ewg.org

Environmental Working Group, 1250 I Street NW, Suite 1000, Washington, DC 20005, USA

\section{Introduction}

The health risk assessment of non-ionizing electromagnetic radiation generated science and policy debates for decades, particularly around the health effects of radiofrequency radiation (RFR) in the $3 \mathrm{kHz}$ to $300 \mathrm{GHz}$ original author(s) and the source, provide a link to the Creative Commons licence, and indicate if changes were made. The images or other third party material in this article are included in the article's Creative Commons licence, unless indicated otherwise in a credit line to the material. If material is not included in the article's Creative Commons licence and your intended use is not permitted by statutory regulation or exceeds the permitted use, you will need to obtain permission directly from the copyright holder. To view a copy of this licence, visit http://creativecommons.org/licenses/by/4.0/. The Creative Commons Public Domain Dedication waiver (http://creativeco mmons.org/publicdomain/zero/1.0/) applies to the data made available in this article, unless otherwise stated in a credit line to the data. 
frequency range used for wireless communications [1-4]. Among the reported biological effects of electromagnetic fields are harm to fetal growth and development [5-13], changes in heart rate variability [14, $15]$, changes in brain activity [16, 17], and elevated risk of several cancers [18-21]. In 2011, the International Agency for Research on Cancer (IARC) classified radiofrequency electromagnetic fields as "possibly carcinogenic to humans" based on an increased risk of glioma, a malignant brain cancer, associated with cellular phone use [18].

The mechanisms by which radiofrequency radiation affects cells, tissues, and organisms are not well understood and may include diverse processes such as inhibition of the mitotic spindle apparatus leading to impaired cell division and cell death [22], changes in the activity of voltage-gated calcium channels [23-26], changes in the concentrations of reactive oxygen species and redox homeostasis [25, 27-32], changes in intracellular enzymes and gene expression [33], and changes in membrane permeability [34]. DNA damage following exposure to RFR $[35,36]$ may be a direct effect or due to secondary mechanisms, such as interference with DNA repair processes [37]. As summarized in a recent review, these biological effects of RFR occur without substantial temperature increases in tissues [27]. Highlighting the complexity of these biological interactions, some forms of electromagnetic fields, described as "tumor treating fields" in the medical research literature, are now explored as a potential therapy for glioblastoma and other cancers [22,38].

With a continuously growing variety of RFR sources in the everyday environment and drastically increased intensity of daily exposure to RFR from personal wireless devices and from short- and long-range sources such as Wi-Fi routers, cell phone towers, and small cell transmitters, the question of safe exposure levels for the public, especially children, is urgent and important. In the U.S., general population exposure standards for RFR were set by the Federal Communications Commission in 1996 based on studies conducted in the 1970s and 1980s in which behavior changes were observed in laboratory animals exposed to RFR for the duration of minutes to hours $[2,39,40]$. For the frequency range of $100 \mathrm{kHz}$ to $6 \mathrm{GHz}$, the U.S. standards define the legally allowable exposures in terms of Specific Absorption Rate, or SAR, which refers to the relative amount of energy absorbed by biological tissues. For non-occupational exposures, U.S. regulations allow a SAR of $0.08 \mathrm{~W} / \mathrm{kg}$ averaged over the whole body and a localized peak spatial SAR of $1.6 \mathrm{~W} /$ $\mathrm{kg}$ averaged over $1 \mathrm{~g}$ of tissue. Localized peak SAR limits apply to wireless device use in immediate contact with the body, for example a cellular phone held near the head.
In the past two decades, epidemiological studies reported an elevated risk of gliomas, acoustic neuromas, parotid gland tumors, and thyroid cancers in regular cellular phone users. The challenge of ascertaining the length, frequency, and intensity of wireless device use and continuously changing communication technologies make it difficult to develop a precise exposure metric from epidemiological research. Recent studies of RFR in laboratory animals provide much-needed information on the specific RFR exposure levels associated with elevated risks of adverse health effects [41]. The results from two long-term, large-scale studies of RFR in laboratory rodents, the study from the U.S. National Toxicology Program (NTP) [42] and the study from the Ramazzini Institute in Italy $[7,43]$, are especially informative. The NTP study examined the health effects of the RFR exposure of interim duration ( 19 weeks, including the prenatal period) and long-term exposure (2 years) and reported cardiotoxic, genotoxic, and carcinogenic effects [35, 4446]. In the Ramazzini Institute study, rats were exposed from prenatal life until natural death, and a statistically significant increase in the incidence of heart schwannomas was reported [7]. Here we model the health effects incidence data from the National Toxicology Program (NTP) to estimate the departure points for exposure guidelines and to open the discussion of exposure limits for wireless devices that would protect the health of vulnerable populations, especially children.

\section{Methods}

Lesion incidence data were accessed from the National Toxicology Program (NTP) reports [20, 21]. The NTP examined the effects of RFR with two different modulations, Code Division Multiple Access (CDMA) and Global System for Mobile Communications (GSM), and in two species: rats and mice, exposed to $900 \mathrm{MHz}$ and $1900 \mathrm{MHz}$ radiation, respectively [44, 45]. Animals were exposed every day for the duration of the analysis, and the length of daily RFR exposure totaled $9 \mathrm{~h}, 10 \mathrm{~min}$ per day, achieved via $18 \mathrm{~h}, 20$ min daily exposure in 10-min on-off cycles. The study design for the two species differed with respect to early life exposure. Rats were exposed from the prenatal period, starting on gestation day 5 , during the 3 -week lactation period, and continuing for the rest of the two-year study duration, with wholebody SAR levels of 1.5, 3, and $6 \mathrm{~W} / \mathrm{kg}$ [44]. For mice, daily exposure with whole-body SAR levels of $2.5,5$, or $10 \mathrm{~W} /$ $\mathrm{kg}$ started at 5-6 weeks of age, around the age of puberty in this species [45]. The NTP study reported an increased incidence of cardiomyopathy in female and male rats and increased incidences of various neoplasms in male rats [44]. In contrast, similar effects were not observed in mice [45]. For the analysis here, we focused on the 
data from rats because that dataset reflects the potential health impacts of life-long exposure to radiofrequency radiation starting from the prenatal period.

Benchmark dose modeling for non-neoplastic and neoplastic incidence data was conducted using U.S. EPA Benchmark Dose Software (BMDS) version 3.2 (https://www.epa.gov/bmds). For non-neoplastic effects, we used both frequentist and Bayesian model averaging options within the BMDS software. For neoplastic effects, we used the frequentist multistage cancer model (MS Combo) following the U.S. EPA's technical guidance for modeling tumor data [47]. The benchmark approach considers the response at all doses tested in the study and can help fill the data gap regarding the shape of the dose-response curve below the lowest dose tested. As discussed in the benchmark dose modeling research literature [48-50], the best fitting models were selected based on the lowest Akaike Information Criterion, goodness-of-fit p values, scaled residual, and visual inspection of the curve fit.

For benchmark modeling, the choice of the appropriate percentage change in the response above the background depends on the specific dataset [47]. Peer-reviewed literature and guidance documents on BMD modeling published by authoritative agencies have used BMD modeling with $5 \%$ or $10 \%$ extra risk $[47,48,50]$. Here we applied the standard approach of calculating the benchmark dose $\left(\mathrm{BMD}_{10}\right)$ at a $10 \%$ benchmark response for non-neoplastic incidence data. For neoplastic incidence data, we conducted modeling of both $5 \%$ and $10 \%$ benchmark response above the background and selected the $5 \%$ response rate $\left(\mathrm{BMD}_{5}\right)$ as an approach that allowed for successful modeling of the neoplasm incidence data from the NTP study. BMDS software also calculates the 95\% lower confidence limit (BMDL) on the exposure level that would produce a response at a selected incidence frequency above the background [47]. BMDL values can be used as a point of departure for the development of health-based guidelines and risk assessment.

\section{Results}

Analysis of dose-response patterns for different lesions observed in the NTP study suggests that some health effects associated with RFR exposures exhibit nonmonotonic dose-response relationships that may be influenced by gender and RFR modulation. RFR exposure corresponding to whole-body SAR of $1.5 \mathrm{~W} / \mathrm{kg}$, the lowest tested level in the NTP study, was associated with an increase in the incidence of various nonneoplastic and neoplastic effects relative to sham-exposed animals, indicating that "No Observed Adverse Effect Level", or NOAEL, was not identified in the NTP study. For some health outcomes, the highest incidence in the RFR-exposed versus control group was observed at $1.5 \mathrm{~W} / \mathrm{kg}$ exposure, with a decrease in incidence at SAR values of 3 and $6 \mathrm{~W} / \mathrm{kg}$.

The findings for cardiomyopathy are particularly compelling. Cardiomyopathy is defined in the NTP report as the "degeneration and necrosis of myofibers with a mild inflammatory response of macrophages and lymphocytes with occasional neutrophils [44]". While observed in both males and females and at both RFR modulations, doseresponse relationships were distinct for right ventricle versus all sites cardiomyopathy. At 19 weeks of exposure, CDMA-exposed male rats had a lower incidence of right ventricle cardiomyopathy in the 3 and $6 \mathrm{~W} / \mathrm{kg}$ dose groups compared to the $1.5 \mathrm{~W} / \mathrm{kg}$ dose group, an effect that was not observed in GSM-exposed male rats at the same time point (Fig. 1A). For all sites cardiomyopathy, male rats in the highest-dose GSM group (SAR $6 \mathrm{~W} /$ $\mathrm{kg}$ ) had lower incidence compared to male rats in the second-highest dose group of $3 \mathrm{~W} / \mathrm{kg}$, while for CDMAexposed male rats all sites cardiomyopathy incidence was the same for the 3 and $6 \mathrm{~W} / \mathrm{kg}$ groups (Fig. 1B). At 19 weeks, cardiomyopathy incidence in females was lower than in males and did not exhibit a dose-response relationship (Fig. 1). At 2 years, right ventricle cardiomyopathy in both CDMA- and GSM exposed rats exhibited a visible dose-response relationship (Fig. 2A), which was not observed for all sites cardiomyopathy (Fig. 2B). Overall, increased incidence of cardiomyopathy both at the interim examination point of 19 weeks and at the end of the study reinforces the health significance of the findings.

We conducted BMDS modeling for all available cardiomyopathy datasets from the NTP study. Successful model fitting was observed for all sites cardiomyopathy in male rats at 19 weeks of exposure and for right ventricle cardiomyopathy in both male and female rats at the 2-year point (Supplementary Table 1). Figures 3 and 4 illustrate the modeling results for all sites cardiomyopathy in male rats at 19 weeks for CDMA (Fig. 3A) and GSM modulations (Fig. 3B) and right ventricle cardiomyopathy in female rats at 2 years for CDMA (Fig. 4A) and GSM (Fig. 4B). Different BMDS frequentist models resulted in similar or identical BMD values and comparable quality of data fit (Supplementary Table 1). Due to the lack of biological information for determining which mathematical model would be most appropriate for the datasets analyzed here, we used the Bayesian model averaging approach to define the $B M D_{10}$ and $B M D L_{10}$ values. Since the highest variability in the dose-response relationship was observed at the highest SAR exposure dose, we conducted modeling with and without this data point (Supplementary Table 2 and Table 1 ). 

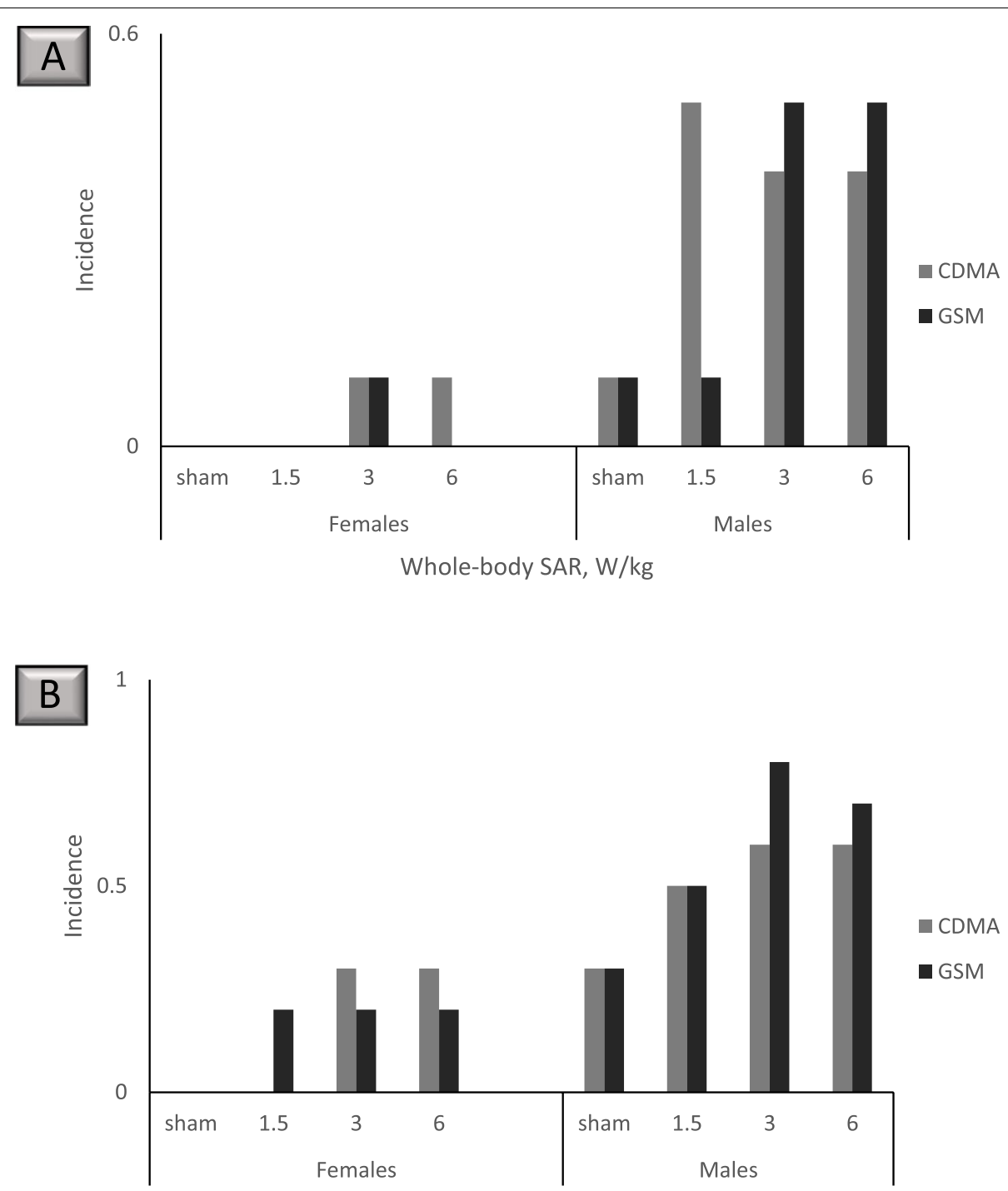

Whole-body SAR, W/kg

Fig. 1 Cardiomyopathy incidence at 19 weeks. Each experimental group had 10 animals. Where no bar is shown, the specific outcome in question was not observed in the animal group. A Right ventricle cardiomyopathy. B All sites cardiomyopathy

While BMD modeling of the datasets without the highest dose of $6 \mathrm{~W} / \mathrm{kg}$ SAR generally resulted in better model fit, overall BMD and BMDL values were comparable for modeling with and without the highest dose (Supplementary Table 1). For male rats at 19 weeks of exposure, the most sensitive responses were observed for GSM, with $0.2-0.29 \mathrm{w} / \mathrm{kg} \mathrm{BMDL} \mathrm{B}_{10}$, compared to $0.27-0.42 \mathrm{~W} /$ $\mathrm{kg} \mathrm{BMDL} 10$ value for CDMA (Table 1). The range of values reported corresponds to modeling with the highest dose included $(0.42 \mathrm{~W} / \mathrm{kg}$ for CDMA and $0.29 \mathrm{~W} / \mathrm{kg}$ for GSM) and excluded $(0.27 \mathrm{~W} / \mathrm{kg}$ for CDMA and $0.2 \mathrm{~W} / \mathrm{kg}$ for GSM).
BMD modeling of right ventricle cardiomyopathy data for female and male rats following a 2-year exposure resulted in consistently lower BMD and BMDL values for males compared to females, indicating greater susceptibility of males to RFR-induced cardiomyopathy (Supplementary Tables 1 and 2). $\mathrm{BMDL}_{10}$ for right ventricle cardiomyopathy in females corresponded to $2.7-5.16 \mathrm{~W} /$ $\mathrm{kg}$ whole-body SAR for CDMA and 1.91-2.18 W/kg for GSM modulation (Table 2). In male rats, the corresponding $\mathrm{BMDL}_{10}$ values were $0.7-0.79 \mathrm{~W} / \mathrm{kg}$ whole-body SAR for CDMA and $0.33-0.42 \mathrm{~W} / \mathrm{kg}$ for GSM modulation (Table 2). 

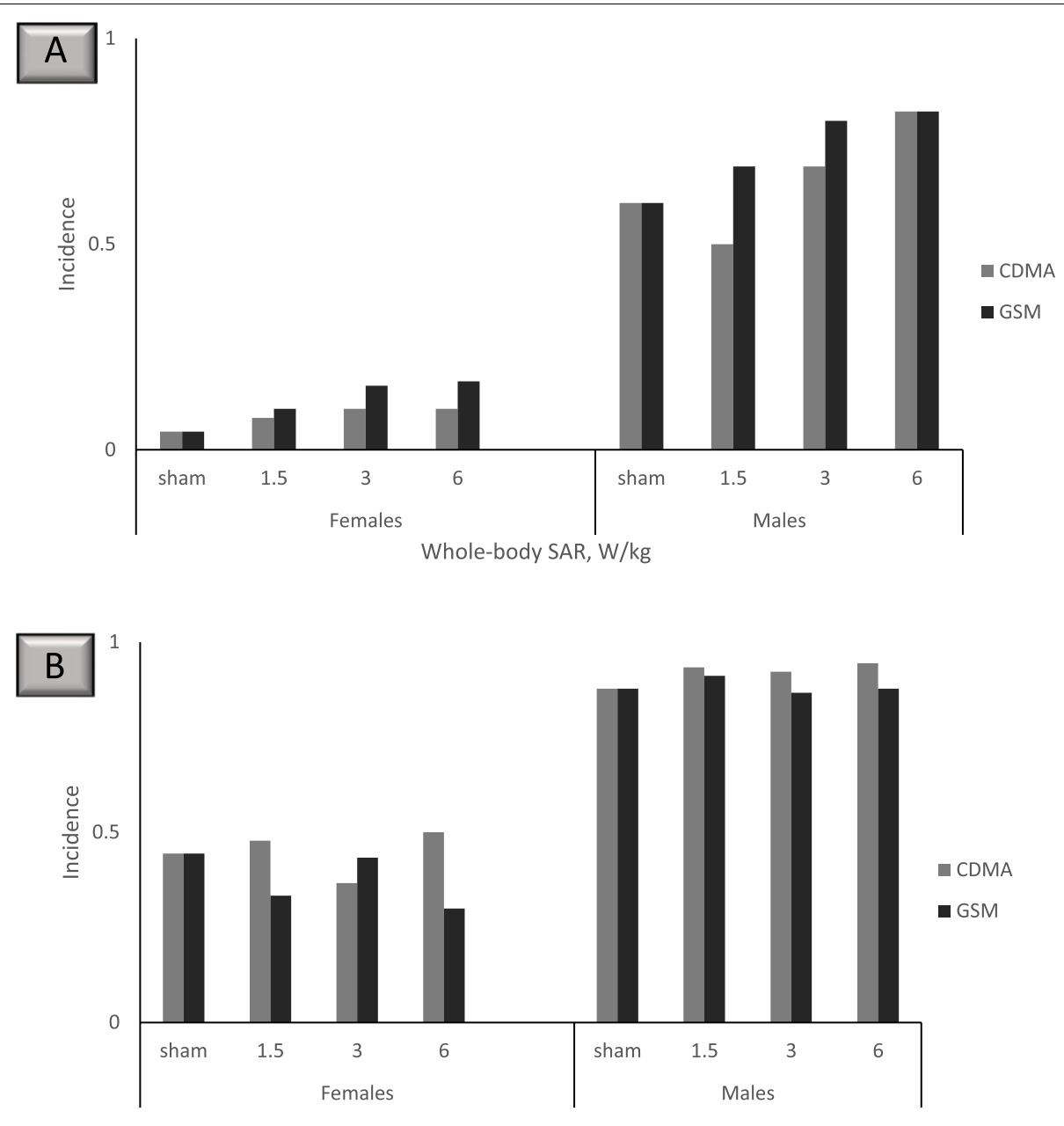

Whole-body SAR, W/kg

Fig. 2 Cardiomyopathy incidence at 2 years. Each experimental group had 90 animals. A Right ventricle cardiomyopathy. B All sites cardiomyopathy

Non-monotonic dose-response relationships were also observed in the NTP dataset for hyperplasias (Fig. 5). The incidence of prostate gland hyperplasia in male rats and adrenal medulla effects in female rats increased and decreased along the range of exposure doses tested (Fig. 5). A complex dose-response relationship also was seen for the tumors in the heart, brain, pituitary gland, adrenal medulla, prostate gland, and liver. For certain outcomes, animals in the $6 \mathrm{~W} / \mathrm{kg}$ exposure group had the highest incidence, such as heart schwannomas in CDMA- and GSM- exposed male rats (Fig. 6A). In contrast, a decrease in incidence in the $6 \mathrm{~W} / \mathrm{kg}$ groups was observed for several neoplasms, such as adrenal medulla neoplasms in CDMA-exposed female rats (Fig. 5), pituitary gland adenomas in CDMA-exposed male rats (Fig. 6B), and adrenal medulla and prostate gland neoplasms in GSM-exposed male rats (Fig. 6B).
Frequentist modeling of benchmark values for adrenal medulla hyperplasia in female rats and prostate gland epithelium hyperplasia in male rats following a 2-year exposure resulted in $\mathrm{BMD}_{10}$ higher than $\mathrm{BMD}_{10}$ values for cardiomyopathy (Supplementary Table 3). Most of the modeled $\mathrm{BMDL}_{10}$ values for these two health outcomes were in the range of $1-3 \mathrm{~W} / \mathrm{kg}$ whole-body SAR. Similar to the greater sensitivity of males to RFR-induced cardiomyopathy compared to females, prostate gland epithelium hyperplasia in males was a more sensitive outcome than adrenal medulla hyperplasia in females (Fig. 5, Supplementary Table 3).

Following the approaches recommended by the U.S. EPA BMDS technical guidance [47] and the published methods for tumor data modeling from the California Environmental Protection Agency Office of Environmental Health Hazard Assessment [51], we modeled the benchmark values for specific neoplasms as well as 

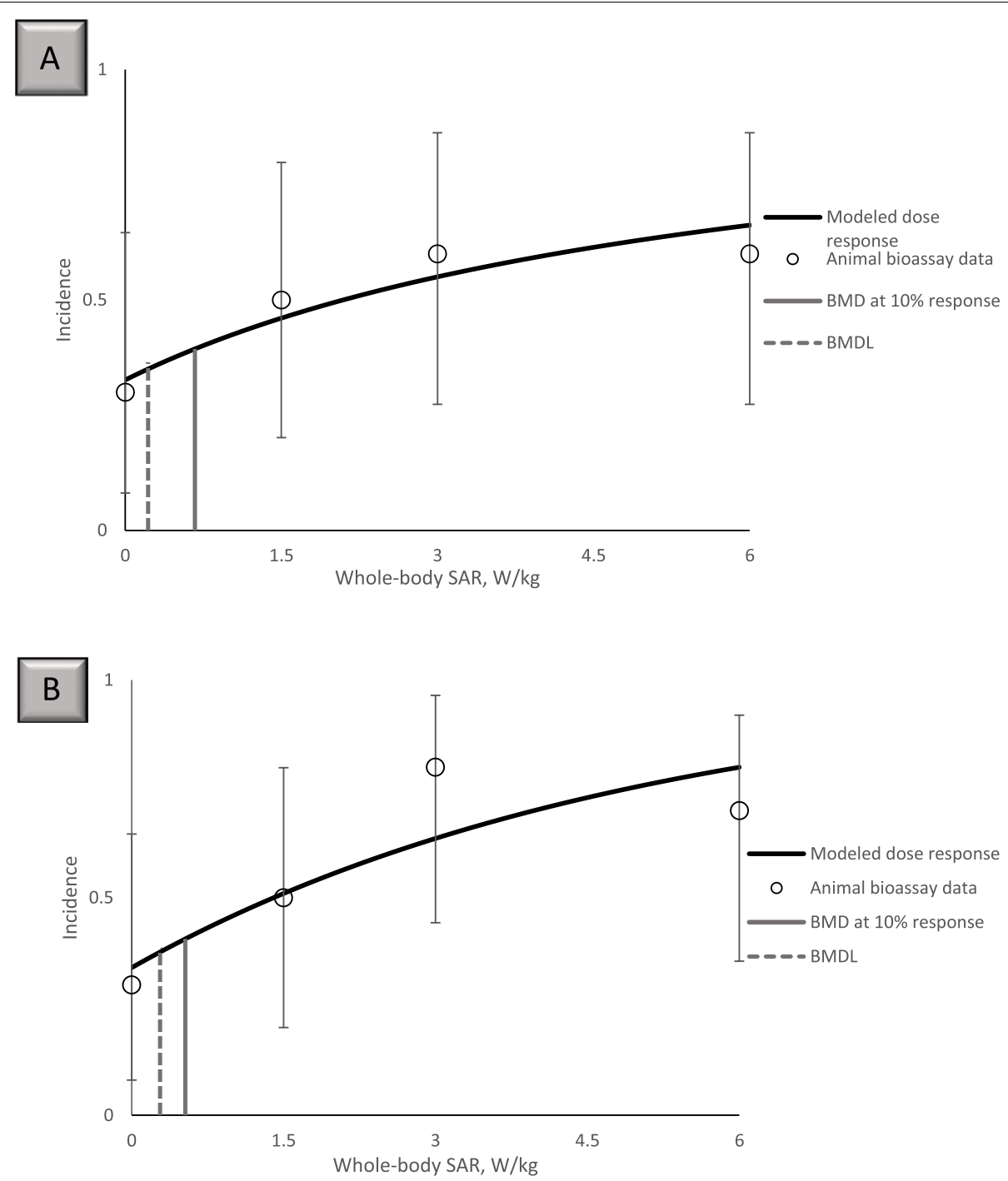

Fig. 3 Benchmark dose modeling of all sites cardiomyopathy in male rats at 19 weeks. A Fitting of the data for CDMA exposures to the log-logistic model results in $\mathrm{BMD}_{10}$ of $0.67 \mathrm{~W} / \mathrm{kg}$ and $B M L_{10}$ of $0.22 \mathrm{~W} / \mathrm{kg}$. $\mathbf{B}$ Fitting of the data for $G S M$ exposures to the Weibull model results in $B M D_{10}$ of $0.54 \mathrm{~W} / \mathrm{kg}$ and $\mathrm{BMDL}_{10}$ of $0.24 \mathrm{~W} / \mathrm{kg}$

multi-site tumor incidence in male rats. Neoplasm incidences in female rats could not be modeled. For male rats, the non-monotonic dose-response relationship patterns precluded BMDS modeling of certain tumor outcomes using all exposure dose groups (Supplementary Tables 4 and 5). Using all exposure dose groups, heart schwannoma data for male rats could be modeled for both CDMA and GSM exposures with 5\% and 10\% change in response rate above background (Table 3). With $10 \%$ response modeling for heart schwannoma, calculated $\mathrm{BMD}_{10}$ values exceeded the SAR value of $6 \mathrm{~W} /$ $\mathrm{kg}$ for the highest exposure dose group in the study, suggesting that the $10 \%$ response modeling is not practical for some tumor types in this dataset.

The omission the highest exposure dose group and the use of $5 \%$ BMR as the modeling approach allowed the modeling of more tumor outcomes, providing an acceptable fit to the remaining dose-response data (Supplementary Table 5 and Table 4). Omission of the highest exposure dose also allowed the modeling of combined incidences of different tumors, which is a modeling option provided in the U.S. EPA BMDS software (Table 4). Modeling of combined tumor outcomes allowed for greater sensitivity and resulted in lower BMD values compared to modeling of individual tumor 

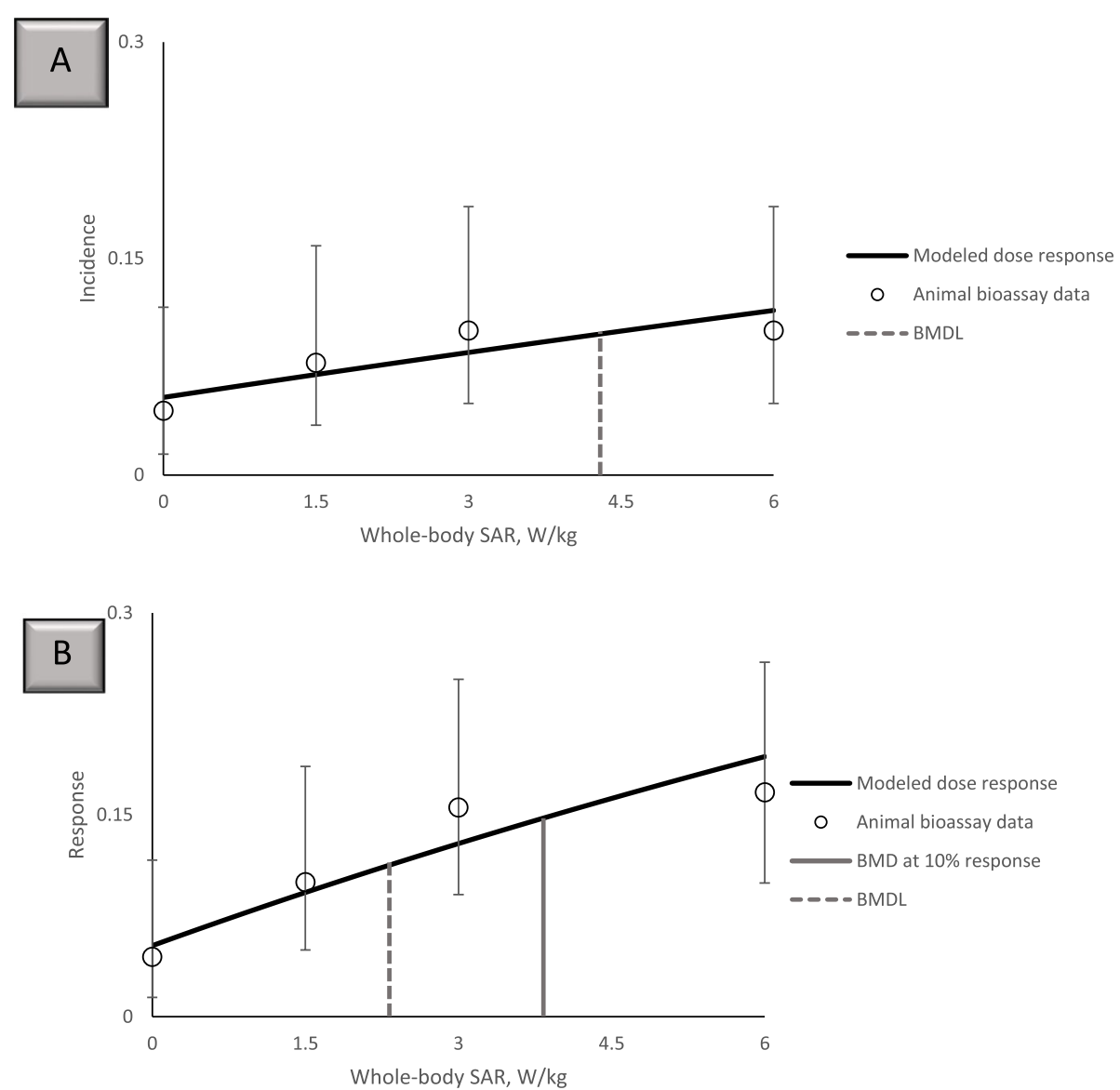

Fig. 4 Benchmark dose modeling of right ventricle cardiomyopathy in female rats at 2 years. A Fitting of the data for CDMA exposures to the log-logistic model results in $\mathrm{BMD}_{10}$ of $9.80 \mathrm{~W} / \mathrm{kg}$ (above the highest dose of $6 \mathrm{~W} / \mathrm{kg}$ tested in the NTP study, and thus not shown in the panel) and $\mathrm{BMDL}_{10}$ of $4.30 \mathrm{~W} / \mathrm{kg}$. B Fitting of the data for GSM exposures to the log-logistic model results in $\mathrm{BMD}_{10}$ of $3.83 \mathrm{~W} / \mathrm{kg}$ and $\mathrm{BMDL}_{10}$ of $2.32 \mathrm{~W} / \mathrm{kg}$

Table $1 \mathrm{BMD}_{10}$ and $\mathrm{BMDL}_{10} \mathrm{SAR}$ values calculated with Bayesian model averaging for all sites cardiomyopathy in male rats following 19 weeks of exposure

\begin{tabular}{lll}
\hline & CDMA & GSM \\
\hline $\mathrm{BMD}_{10}$, all doses & $1.75 \mathrm{~W} / \mathrm{kg}$ & $0.94 \mathrm{~W} / \mathrm{kg}$ \\
$\mathrm{BMDL}_{10}$, all doses & $0.42 \mathrm{~W} / \mathrm{kg}$ & $0.29 \mathrm{~W} / \mathrm{kg}$ \\
$\mathrm{BMD}_{10}$, the highest dose omitted & $0.97 \mathrm{~W} / \mathrm{kg}$ & $0.58 \mathrm{~W} / \mathrm{kg}$ \\
$\mathrm{BMDL}_{10}$, the highest dose omitted & $0.27 \mathrm{~W} / \mathrm{kg}$ & $0.20 \mathrm{~W} / \mathrm{kg}$ \\
\hline
\end{tabular}

incidences. Even with the omission of the highest dose, $\mathrm{BMD}_{10}$ values could not be modeled for heart schwannoma, brain meninges neoplasm, and combined tumors for GSM exposure (Table 4).

The combined neoplasm incidence data could be modeled with a $5 \%$ increased incidence above background in the dataset without the highest dose (Table 4). BMDL value of $0.31 \mathrm{~W} / \mathrm{kg}$ whole-body SAR was calculated for combined tumors in CDMA-exposed rats and $\mathrm{BMDL}_{5}$ value of $0.21 \mathrm{~W} / \mathrm{kg}$ was calculated for GSM. These $\mathrm{BMDL}_{5}$ values for combined tumor incidence are overall comparable to the $\mathrm{BMDL}_{10}$ values for cardiomyopathy effects. Of note, throughout our analysis, BMD and BMDL values were consistently lower for GSM-exposed animals relative to CDMA exposures, indicating greater sensitivity to GSM modulation in the NTP study.

\section{Discussion}

Radiofrequency radiation can elicit carcinogenic, genotoxic, reproductive, developmental, neurological, and cognitive effects [52-54]. Continuously increasing exposure to radiofrequency radiation from wireless communication devices and sources brings urgency to the question of health-protective limits for such exposures. Here we use benchmark dose modeling as an approach to develop health-based exposure limits for RFR based on animal toxicology data. The lower limit on the modeled benchmark dose, abbreviated as BMDL, offers a 
Table $2 \mathrm{BMD}_{10}$ and $\mathrm{BMDL}_{10}$ SAR values calculated with Bayesian model averaging for right ventricle cardiomyopathy in male and female rats following a 2-year exposure

\begin{tabular}{|c|c|c|c|c|}
\hline & $\begin{array}{l}\text { Females } \\
\text { CDMA }\end{array}$ & $\begin{array}{l}\text { Females } \\
\text { GSM }\end{array}$ & $\begin{array}{l}\text { Males } \\
\text { CDMA }\end{array}$ & $\begin{array}{l}\text { Males } \\
\text { GSM }\end{array}$ \\
\hline $\mathrm{BMD}_{10}$, all doses & $10.68 \mathrm{~W} / \mathrm{kg}^{\mathrm{a}}$ & $4.86 \mathrm{~W} / \mathrm{kg}$ & $1.50 \mathrm{~W} / \mathrm{kg}$ & $0.81 \mathrm{~W} / \mathrm{kg}$ \\
\hline $\mathrm{BMDL}_{10}$, all doses & $5.16 \mathrm{~W} / \mathrm{kg}$ & $2.18 \mathrm{~W} / \mathrm{kg}$ & $0.70 \mathrm{~W} / \mathrm{kg}$ & $0.42 \mathrm{~W} / \mathrm{kg}$ \\
\hline $\mathrm{BMD}_{10}$, the highest dose omitted & $5.21 \mathrm{~W} / \mathrm{kg}$ & $2.94 \mathrm{~W} / \mathrm{kg}$ & $1.69 \mathrm{~W} / \mathrm{kg}$ & $0.69 \mathrm{~W} / \mathrm{kg}$ \\
\hline $\mathrm{BMDL}_{10}$, the highest dose omitted & $2.70 \mathrm{~W} / \mathrm{kg}$ & $1.91 \mathrm{~W} / \mathrm{kg}$ & $0.79 \mathrm{~W} / \mathrm{kg}$ & $0.33 \mathrm{~W} / \mathrm{kg}$ \\
\hline
\end{tabular}

${ }^{\text {a }}$ Calculated $\mathrm{BMD}_{10}$ value is greater than the $6 \mathrm{~W} / \mathrm{kg}$ highest SAR exposure dose in the study

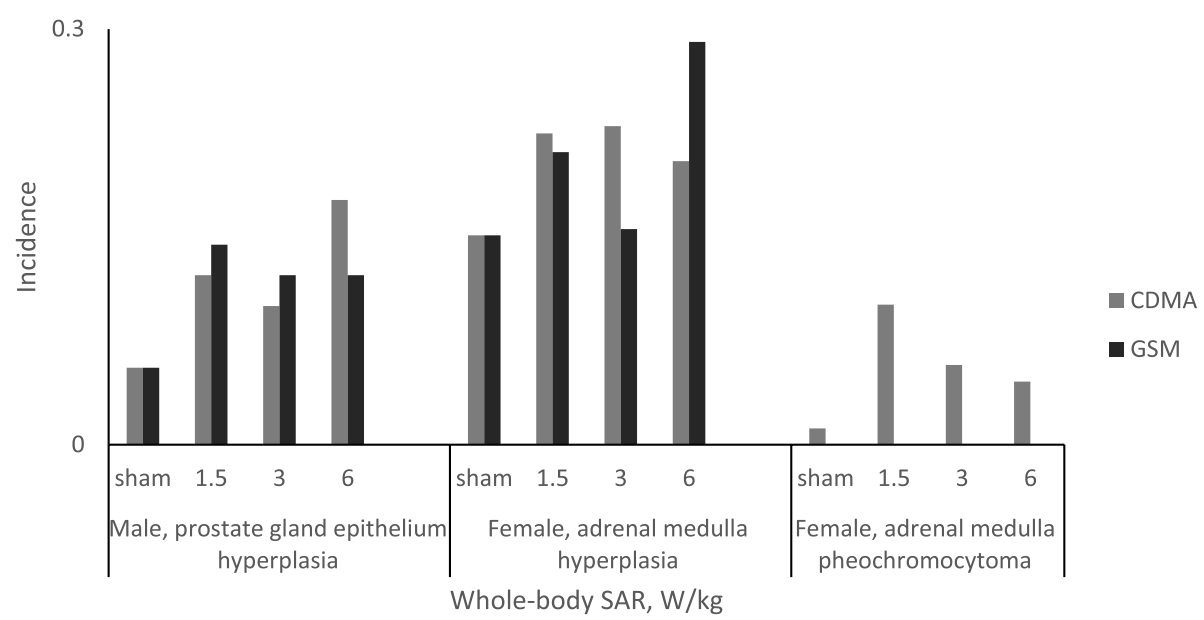

Fig. 5 Prostate gland hyperplasia in male rats and adrenal medulla effects in female rats at 2 years

95\% statistical estimate on the exposure dose associated with a $5 \%$ or a $10 \%$ change in response rate, which can be treated as a point of departure for the development of health-based exposure guidelines. To extrapolate from a point of departure from animal toxicological studies to the exposure level acceptable for the human population, safety factors are commonly used, including a tenfold factor for differences between species (humans and laboratory animals, in this case) and a second tenfold factor for variability in the potential sensitivity within the human population [55]. The use of these two tenfold safety factors comes from a decades-old practice in chemical risk assessment. It is possible that the range of variations in sensitivity within the human population and the range of differences between species may not be captured in the conventionally applied ten-fold factors. Further, to protect sensitive populations such as children, an additional safety factor may be necessary, an approach first introduced for pesticide risk assessment to account for susceptibilities during the vulnerable stages of early development [56].

Among the BMDL values calculated in this study, the most sensitive values were $\mathrm{BMDL}_{10}$ for all sites cardiomyopathy at 19 weeks of exposure in male rats. The range of $\mathrm{BMDL}_{10}$ values 0.2 to $0.4 \mathrm{~W} / \mathrm{kg}$, listed in Table 1, offers a point of departure for defining exposure limits. The application of two ten-fold safety factors for interspecies and intraspecies variability (combined 100X factor) to the point of departure suggests a whole-body SAR limit of 2 to $4 \mathrm{~mW} / \mathrm{kg}$ for adults (Fig. 7). These SAR values are 20- to 40 -fold smaller than the current U.S. whole-body SAR limit of $0.08 \mathrm{~W} / \mathrm{kg}$. Application of an additional ten-fold safety factor to account for the greater sensitivity of the developing organism points to a whole-body SAR limit of 0.2 to $0.4 \mathrm{~mW} / \mathrm{kg}$ for the young child.

We note two key differences between the health-based exposure limits presented here and the current U.S. regulations for radiofrequency radiation which set the limits of $0.08 \mathrm{~W} / \mathrm{kg}$ for the whole-body SAR and the localized spatial peak of $1.6 \mathrm{~W} / \mathrm{kg}$ SAR as averaged over $1 \mathrm{~g}$ of tissue. These differences are in the selection of the point of departure and the application of safety factors. The existing U.S. radiofrequency radiation standards were based on the 1986 recommendations of the U.S. National Council on Radiation Protection and Measurements and 


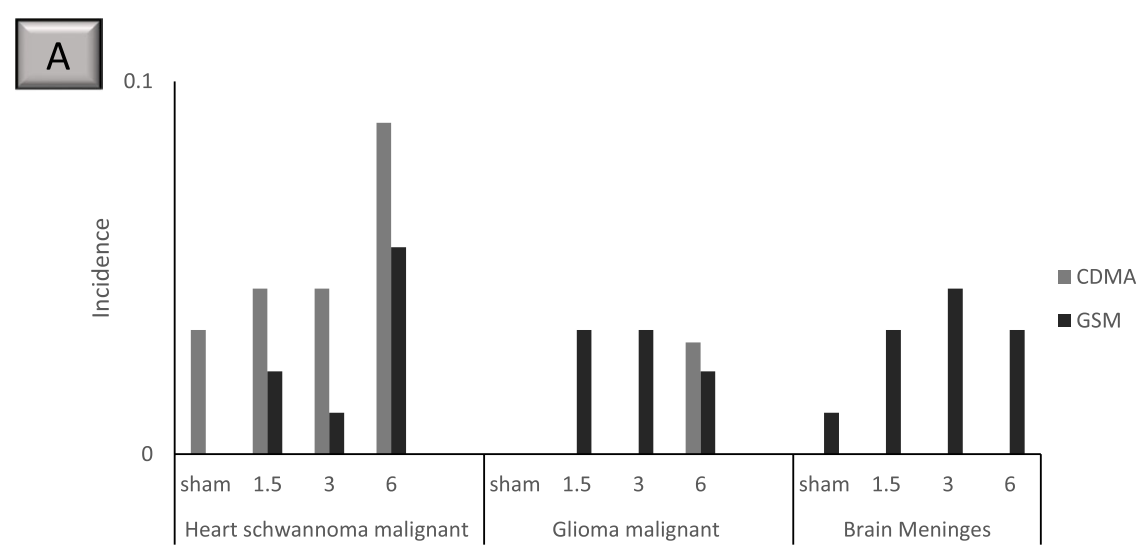

Whole-body SAR, W/kg

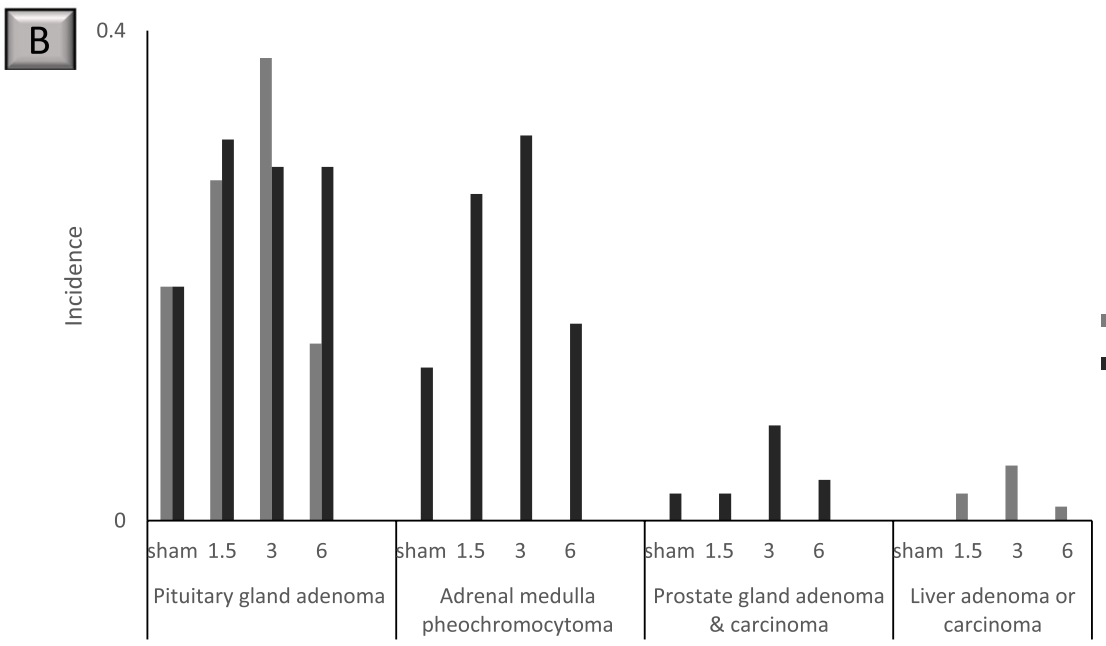

Whole-body SAR, W/kg

Fig. 6 Neoplasm incidence in male rats at 2 years. Where no bar is shown, the specific outcome in question was not observed in the animal group. A Heart and brain tumors. B Pituitary gland, adrenal medulla, prostate gland, and liver tumors

Table 3 BMDS modeling of cancer incidence in male rats using the MS Combo model. Neoplasm incidence data analyzed here included all exposure groups

\begin{tabular}{|c|c|c|c|c|}
\hline Exposure condition and tumor type & $\mathrm{BMD}_{5}$ & $\mathrm{BMDL}_{5}$ & $\mathrm{BMD}_{10}$ & $\mathrm{BMDL}_{10}$ \\
\hline CDMA, heart schwannoma & 4.29 & 2.71 & $8.82^{\mathrm{a}}$ & 5.40 \\
\hline CDMA, pituitary gland adenoma & \multicolumn{4}{|c|}{ Could not be modeled } \\
\hline CDMA, liver adenoma & \multicolumn{4}{|c|}{ Could not be modeled } \\
\hline CDMA, combined heart schwannoma, liver adenoma, and pituitary gland adenoma & \multicolumn{4}{|c|}{ Could not be modeled } \\
\hline GSM, heart schwannoma & 5.94 & 3.49 & $11.82^{\mathrm{a}}$ & 6.20 \\
\hline GSM, brain malignant glioma & $9.00^{\mathrm{a}}$ & 3.60 & Could not be modeled & \\
\hline GSM, brain meninges neoplasm (benign and malignant) & $11.31^{\mathrm{a}}$ & 3.89 & Could not be modeled & \\
\hline GSM, adrenal medulla pheochromocytoma (benign and malignant) & \multicolumn{4}{|c|}{ Could not be modeled } \\
\hline GSM, pituitary gland adenoma & 2.86 & 1.15 & Could not be modeled & \\
\hline $\begin{array}{l}\text { GSM, combined heart schwannoma, brain glioma, and meninges neoplasm, adrenal } \\
\text { pheochromocytoma, and pituitary gland adenoma }\end{array}$ & \multicolumn{4}{|c|}{ Could not be modeled } \\
\hline
\end{tabular}

a Calculated BMD value is greater than the $6 \mathrm{~W} / \mathrm{kg}$ highest exposure dose in the NTP study 
Table 4 BMDS modeling of cancer incidence in male rats using the MS Combo model. Neoplasm incidence data modeled here did not include the highest exposure dose of $6 \mathrm{~W} / \mathrm{kg}$

\begin{tabular}{|c|c|c|c|c|}
\hline Exposure condition and tumor type & $\mathrm{BMD}_{5}$ & $\mathrm{BMDL}_{5}$ & $\mathrm{BMD}_{10}$ & $\mathrm{BMDL}_{10}$ \\
\hline CDMA, heart schwannoma & $4.09^{\mathrm{a}}$ & 2.12 & $8.41^{\mathrm{a}}$ & 3.50 \\
\hline CDMA, pituitary gland adenoma & 0.60 & 0.37 & 1.23 & 0.77 \\
\hline CDMA, liver adenoma & $3.37^{\mathrm{a}}$ & 1.84 & $6.93^{\mathrm{a}}$ & 3.78 \\
\hline CDMA, combined heart schwannoma, liver adenoma, and pituitary gland adenoma & 0.45 & 0.31 & 0.93 & 0.63 \\
\hline GSM, heart schwannoma & $6.87^{\mathrm{a}}$ & 3.01 & Could not be modeled & \\
\hline GSM, brain malignant glioma & $3.40^{\mathrm{a}}$ & 1.86 & $6.99^{\mathrm{a}}$ & 3.46 \\
\hline GSM, brain meninges neoplasm (benign and malignant) & $4.21^{\mathrm{a}}$ & 1.90 & Could not be modeled & \\
\hline GSM, adrenal medulla pheochromocytoma (benign and malignant) & 0.58 & 0.38 & 1.20 & 0.78 \\
\hline GSM, pituitary gland adenoma & 1.06 & 0.51 & 2.17 & 1.06 \\
\hline $\begin{array}{l}\text { GSM, combined heart schwannoma, brain glioma, and meninges neoplasm, adrenal } \\
\text { pheochromocytoma, and pituitary gland adenoma }\end{array}$ & 0.30 & 0.21 & Could not be modeled & \\
\hline
\end{tabular}

${ }^{a}$ Calculated BMD value is greater than the $3 \mathrm{~W} / \mathrm{kg}$ highest exposure dose included in this analysis

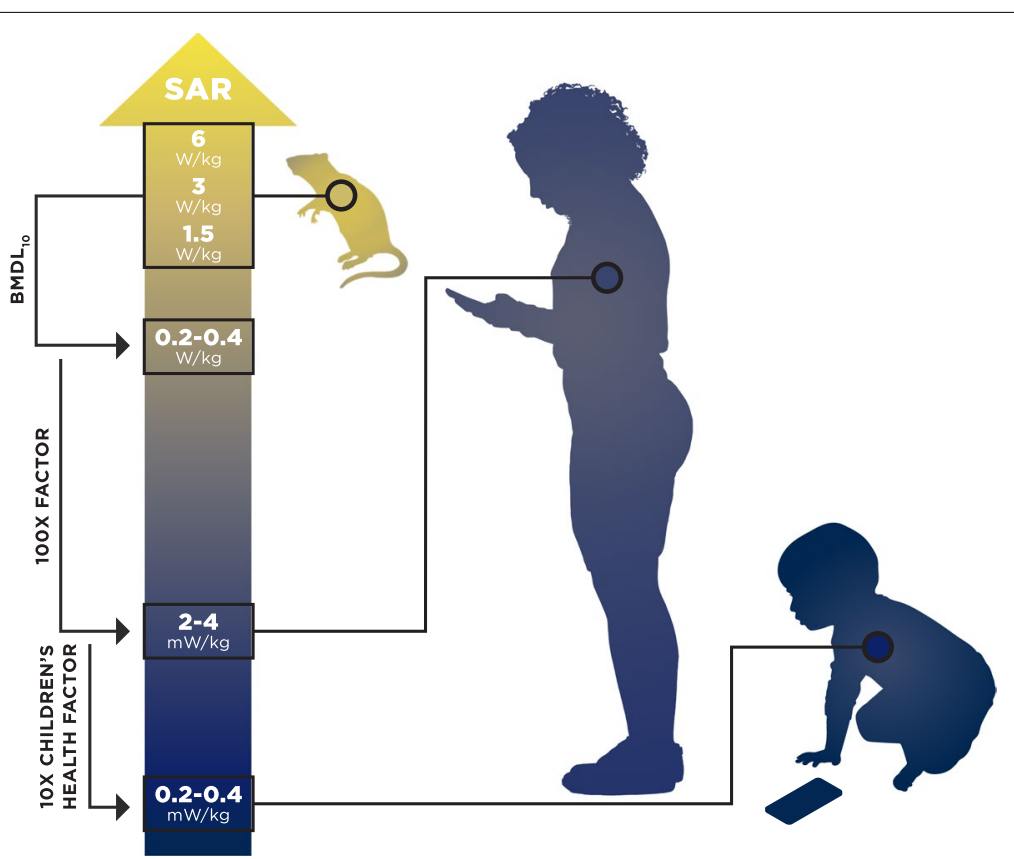

Fig. 7 Summary of health-based exposure limits calculated in this study. Whole-body SAR value of 0.2-0.4 W/kg was selected as a point of departure for calculating health-based exposure guidelines. Applying two ten-fold safety factors for interspecies and intraspecies variability (a total of 100X), a whole-body SAR limit of $2-4 \mathrm{~mW} / \mathrm{kg}$ is derived for adults. The application of an additional ten-fold (10X) children's health factor suggests a limit of $0.2-0.4 \mathrm{~mW} / \mathrm{kg}$ whole body SAR for young children

1991 recommendations of the Institute of Electrical and Electronics Engineers [2, 40], which chose SAR value of $4 \mathrm{~W} / \mathrm{kg}$ as the point of departure based on changes in animal behavior observed in studies conducted in the late 1970s and early 1980s.

The regulatory limit of $0.08 \mathrm{~W} / \mathrm{kg}$ whole-body SAR was calculated by the application of two factors, a tenfold factor and a five-fold factor (combined 50X) to the $4 \mathrm{~W} / \mathrm{kg}$ SAR point of departure. While the first ten-fold factor accounted for the translation from animals to humans, the five-fold factor, proposed in the 1986 report by the U.S. National Council on Radiation Protection and Measurements, related to the difference in duration of work-related occupational exposure versus continuous exposure for the general public and not to health considerations [2]. The legal limit of $0.08 \mathrm{~W} / \mathrm{kg}$ wholebody SAR did not include safety factors to account for potential variability in the sensitivity within the human 
population and greater sensitivity of children. The localized SAR limit of $1.6 \mathrm{~W} / \mathrm{kg}$ was defined by multiplying the whole-body SAR limit of $0.08 \mathrm{~W} / \mathrm{kg}$ by a factor of twenty [39, 40]. In the historical context of 1980 s discussions of allowable exposure limits for occupational and general public exposures, the concept of a 20 -fold increase of peak SAR relative to the whole-body SAR was based on the view that increase in tissue temperature was the main effect of radiofrequency radiation [40].

The epidemiological studies of mobile phone users and the reports of an elevated risk of head tumors on the side of the head where the phone was typically used highlight the toxicological importance of peak exposures in the part of the body closest to the wireless device [18-21, 57]. For example, as reported in a study from Israel, there was a $50-60 \%$ increased risk of parotid gland tumors on the ipsilateral side where hand-held mobile devices were used, while on the contralateral side, the risk of parotid gland tumors was not significantly different from controls [19]. Likewise, Hardell and coworkers reported a $90 \%$ increased risk of glioma for long-term ipsilateral exposure of mobile phones [57].

In the NTP study, laboratory animals received wholebody exposure to radiofrequency radiation from specially designed reverberation chambers [44, 45]. A dosimetry analysis for the animals in the NTP study reported the ratios between organ and whole-body SAR values [58]. According to that analysis, the peak SAR in the heart of male rats was 2.7 decibels $(\mathrm{dB})$ higher than the wholebody SAR [58]. This difference of $2.7 \mathrm{~dB}$ between heart and whole-body SAR is much smaller than the 20-fold difference between localized and whole-body SAR assumed in the 1980s publications [39, 40].

In our view, more research is necessary to define what the acceptable, health-protective localized SAR value should be. An appropriate peak spatial SAR can be determined according to the concept of ALARA, or As Low As Reasonably Achievable, a concept developed for human exposures to ionizing radiation. Technical manuals for wireless devices specify that these products are tested for compliance with the SAR values defined under the U.S. Federal Communications Commission regulations, or under the corresponding regulations set by government authorities in other countries. However, investigative reports found that wireless devices may not comply with these regulatory limits if tested in a real-life scenario where the device touches the body directly [59].

Finally, the methodology used for the development of health-based exposure limits, such as the benchmark dose modeling and the application of safety factors, remains an evolving area of research in risk assessment. The lack of information about the shape of the doseresponse curve below the lowest dose tested and the decreased incidence of various lesions observed at the highest dose tested by the NTP $[42,60,61]$ pose questions for future research. The point of departure selected from benchmark modeling presented here, $\mathrm{BMDL}_{10}$ value of $0.2-0.4 \mathrm{~W} / \mathrm{kg}$ whole-body SAR, does not correspond to the true "No Adverse Effects Level", which is likely lower. Falcioni and coworkers reported a No Observed Adverse Effects Level of $0.03 \mathrm{~W} / \mathrm{kg}$ for heart schwannomas in their study [7]. This NOAEL value is between the $\mathrm{BMDL}_{10}$ values calculated here and the health-based limit of $2-4 \mathrm{~mW} / \mathrm{kg}$ for adults that we defined by the application of two ten-fold safety factors. While the use of ten-fold safety factors is an established risk assessment practice in the U.S. and other countries, it is possible that these standard factors either underestimate or overestimate the extent of variability in sensitivity within the human population. Even with the outstanding questions, the NTP and the Ramazzini Institute data on the RFR effects in laboratory animals are a valuable resource for the development of health-based guidelines for RFR exposures in people [41, 42].

\section{Conclusions}

The analysis presented here supports a whole-body SAR limit of 2 to $4 \mathrm{~mW} / \mathrm{kg}$ for adults, an exposure level that is 20 - to 40 -fold lower than the legally permissible limit of $0.08 \mathrm{~W} / \mathrm{kg}$ for whole-body SAR under the current U.S. regulations. A ten-fold lower level of $0.2-0.4 \mathrm{~mW} / \mathrm{kg}$ whole-body SAR may be appropriate for young children. Both technology changes and behavior changes may be necessary to achieve these lower exposure levels. Simple actions, such as keeping the wireless devices farther away from the body, offer an immediate way to decrease RFR exposure for the user.

\section{Supplementary Information}

The online version contains supplementary material available at https://doi. org/10.1186/s12940-021-00768-1.

Additional file 1: Supplementary Table 1. Frequentist modeling of cardiomyopathy in male and female rats. Only models with good visual fit were included. Where several models produced identical BMD values, $p$ values, scaled residuals and Akaike Information Criterion, all models giving the same calculated values are listed. Supplementary Table 2. 10\% BMR estimates for cardiomyopathy calculated with the Bayesian model averaging approach. Model Average values highlighted in bold at the bottom of each row are presented in Tables 1 and 2 of the Results section. Supplementary Table 3. Frequentist modeling of hyperplasias in male and female rats following 2 years of exposure. Only models with good visual fit were included. Supplementary Table 4. 10\% BMR estimates for multistage MS Combo modeling of neoplasm incidence data in male rats at 2 years. Only the datasets that could be modeled are included in this table. Supplementary Table 5. 5\% BMR estimates for multistage MS Combo modeling of neoplasm incidence data in male rats at 2 years. Only the datasets that could be modeled are included in this table. 


\section{Acknowledgements}

The authors gratefully acknowledge the help of their colleagues Sydney Evans, Tiffany Follin, and Katie Peacor for their assistance with visualization and graphics. The authors also acknowledge David Andrews, Tasha Stoiber, Sydney Evans, Alexis Temkin and the journal's peer reviewers who provided technical and scientific feedback on the manuscript.

\section{Authors' contributions}

Uloma Igara Uche: Conceptualization, Formal Analysis, Writing-Original Draft, Writing-Review \& Editing, Visualization Olga V. Naidenko: Conceptualization, Writing-Original Draft, Writing — Review \& Editing. The author(s) read and approved the final manuscript.

\section{Funding}

This research project was supported by a grant from Jonas Philanthropies.

\section{Availability of data and materials}

The datasets analyzed for this study can be found in the published National Toxicology Program technical report https://ntp.niehs.nih.gov/ntp/htdocs/lt_ rpts/tr595_508.pdf?utm_source=direct\&utm_medium=prod\&utm_campa ign=ntpgolinks\&utm_term $=\operatorname{tr} 595$ and on the website of the U.S. National Toxicology Program at https://ntp.niehs.nih.gov/whatwestudy/topics/cellp hones/index.html.

\section{Declarations}

\section{Competing interests}

The authors declare that they have no competing interests.

Received: 3 May 2021 Accepted: 1 July 2021

Published online: 17 July 2021

\section{References}

1. U.S. Environmental Protection Agency. Biological effects of radiofrequency radiation: EPA-600/8-83-026F. Health Effect Research Laboratory, U.S. Environmental Protection Agency. Research Triangle Park; 1984. Available from: https://nepis.epa.gov/Exe/ZyPURL.cgi?Dockey=300065H1.TXT.

2. National Council on Radiation Protection and Measurements. Biological effects and exposure criteria for radiofrequency electromagnetic fields: NCRP Report No. 86; 1986. Available from: https://ncrponline.org/shop/ reports/report-no-086-biological-effects-and-exposure-criteria-for-radio frequency-electromagnetic-fields-1986/.

3. Blackman C. Cell phone radiation: evidence from ELF and RF studies supporting more inclusive risk identification and assessment. Pathophysiology. 2009;16(2-3):205-16. https://doi.org/10.1016/j.pathophys.2009.02. 001.

4. International Commission on Non-lonizing Radiation Protection. Guidelines for limiting exposure to Electromagnetic Fields ( $100 \mathrm{kHz}$ to 300 GHz). Health Phys. 2020;118(5):483-524. https://www.icnirp.org/cms/ upload/publications/ICNIRPrfgdl2020.pdf.

5. Ozgur E, Kismali G, Guler G, Akcay A, Ozkurt G, Sel T, et al. Effects of prenatal and postnatal exposure to GSM-like radiofrequency on blood chemistry and oxidative stress in infant rabbits, an experimental study. Cell Biochem Biophys. 2013;67(2):743-51. https://doi.org/10.1007/ s12013-013-9564-1.

6. Azimzadeh M, Jelodar G. Prenatal and early postnatal exposure to radiofrequency waves $(900 \mathrm{MHz}$ ) adversely affects passive avoidance learning and memory. Toxicol Ind Health. 2020;36(12):1024-30. https://doi.org/10. 1177/0748233720973143.

7. Falcioni L, Bua L, Tibaldi E, Lauriola M, De Angelis L, Gnudi F, et al. Report of final results regarding brain and heart tumors in Sprague-Dawley rats exposed from prenatal life until natural death to mobile phone radiofrequency field representative of a $1.8 \mathrm{GHz}$ GSM base station environmental emission. Environ Res. 2018;165:496-503. https://doi.org/10.1016/j. envres.2018.01.037.

8. Fathy A, Rifaai RA, Said A, Ragab S. Structural changes in the parotid gland of male albino rats following prenatal and postnatal exposure to radiofrequency radiation. Egyptian J Histol. 2015;38(1):102-15. https:// doi.org/10.1097/01.EHX.0000460811.11670.34.

9. Erkut A, Tumkaya L, Balik MS, Kalkan Y, Guvercin Y, Yilmaz A, et al. The effect of prenatal exposure to $1800 \mathrm{MHz}$ electromagnetic field on calcineurin and bone development in rats. Acta Cirurgica Brasileira. 2016;31(2):74-83. https://doi.org/10.1590/S0102-865020160020000001.

10. Lary JM, Conover DL, Foley ED, Hanser PL. Teratogenic effects of 27.12 $\mathrm{MHz}$ radiofrequency radiation in rats. Teratology. 1982;26(3):299-309. https://doi.org/10.1002/tera.1420260312.

11. Magras IN, Xenos TD. RF radiation-induced changes in the prenatal development of mice. Bioelectromagnet J Bioelectromagnet Soc Soc Phys Regul Biol Med Eur Bioelectromagnet Assoc. 1997;18(6):45561. https://doi.org/10.1002/(sici)1521-186x(1997)18:<455::aid-bem8>3. 0.co:2-1.

12. Aerts S, Calderon C, Valič B, Maslanyj M, Addison D, Mee T, et al. Measurements of intermediate-frequency electric and magnetic fields in households. Environ Res. 2017;154:160-70. https://doi.org/10.1016/j. envres.2017.01.001.

13. Ren Y, Chen J, Miao M, Li D-K, Liang H, Wang Z, et al. Prenatal exposure to extremely low frequency magnetic field and its impact on fetal growth. Environ Health. 2019;18(1):6. https://doi.org/10.1186/ s12940-019-0447-9.

14. Szmigielski S, Bortkiewicz A, Gadzicka E, Zmyslony M, Kubacki R. Alteration of diurnal rhythms of blood pressure and heart rate to workers exposed to radiofrequency electromagnetic fields. Blood Press Monit. 1998;3(6):323-30.

15. Wallace J, Andrianome S, Ghosn R, Blanchard ES, Telliez F, Selmaoui B. Heart rate variability in healthy young adults exposed to global system for mobile communication (GSM) 900-MHz radiofrequency signal from mobile phones. Environ Res. 2020;191:110097. https://doi.org/10.1016/j. envres.2020.110097.

16. Wallace J, Selmaoui B. Effect of mobile phone radiofrequency signal on the alpha rhythm of human waking EEG: a review. Environ Res. 2019;175:274-86. https://doi.org/10.1016/j.envres.2019.05.016.

17. Volkow ND, Tomasi D, Wang G-J, Vaska P, Fowler JS, Telang F, et al. Effects of cell phone radiofrequency signal exposure on brain glucose metabolism. JAMA. 2011;305(8):808-13. https://doi.org/10.1001/jama.2011.186.

18. International Agency for Research on Cancer. IARC classifies radiofrequency electromagnetic fields as possibly carcinogenic to humans. Press Release N: 208. 2011. Available from: http://emfguide.itu.int/pdfs/ pr208_E.pdf.

19. Sadetzki S, Chetrit A, Jarus-Hakak A, Cardis E, Deutch Y, Duvdevani S, et al. Cellular phone use and risk of benign and malignant parotid gland tumors - a nationwide case-control study. Am J Epidemiol. 2008;167(4):457-67. https://doi.org/10.1093/aje/kwm325.

20. Luo J, Deziel NC, Huang H, Chen Y, Ni X, Ma S, et al. Cell phone use and risk of thyroid cancer: a population-based case-control study in Connecticut. Ann Epidemiol. 2019;29:39-45. https://doi.org/10.1016/j.annep idem.2018.10.004.

21. Luo J, Li H, Deziel NC, Huang H, Zhao N, Ma S, et al. Genetic susceptibility may modify the association between cell phone use and thyroid cancer: a population-based case-control study in Connecticut. Environ Res. 2020;182:109013. https://doi.org/10.1016/j.envres.2019.109013.

22. Kissling C, Di Santo S. Tumor Treating fields-behind and beyond inhibiting the cancer cell cycle. CNS Neurol Disord-Drug Targets (Formerly Current Drug Targets-CNS \& Neurological Disorders). 2020;19(8):599-610. https://doi.org/10.2174/1871527319666200702144749.

23. Blackman C, Benane S, House D. The influence of temperature during electric-and magnetic-field-induced alteration of calcium-ion release from in vitro brain tissue. Bioelectromagnetics. 1991;12(3):173-82. https:// doi.org/10.1002/bem.2250120305.

24. Oyewopo A, Olaniyi S, Oyewopo C, Jimoh A. Radiofrequency electromagnetic radiation from cell phone causes defective testicular function in male Wistar rats. Andrologia. 2017;49(10):e12772. https://doi.org/10.1111/ and.12772.

25. Ertilav K, Uslusoy F, Ataizi S, Nazıroğlu M. Long term exposure to cell phone frequencies ( 900 and $1800 \mathrm{MHz}$ ) induces apoptosis, mitochondrial oxidative stress and TRPV1 channel activation in the hippocampus and dorsal root ganglion of rats. Metab Brain Dis. 2018;33(3):753-63. https:// doi.org/10.1007/s11011-017-0180-4. 
26. Jimenez H, Wang M, Zimmerman JW, Pennison MJ, Sharma S, Surratt T, et al. Tumour-specific amplitude-modulated radiofrequency electromagnetic fields induce differentiation of hepatocellular carcinoma via targeting Cav3. 2 T-type voltage-gated calcium channels and Ca2+ influx. EBioMedicine. 2019;44:209-24. https://doi.org/10.1016/j.ebiom.2019.05. 034.

27. Belpomme D, Hardell L, Belyaev I, Burgio E, Carpenter DO. Thermal and non-thermal health effects of low intensity non-ionizing radiation: an international perspective. Environ Pollut. 2018;242:643-58. https://doi. org/10.1016/j.envpol.2018.07.019.

28. Sharma A, Sharma S, Shrivastava S, Singhal PK, Shukla S. Mobile phone induced cognitive and neurochemical consequences. J Chem Neuroanat. 2019;102:101684. https://doi.org/10.1016/j.jchemneu.2019. 101684.

29. Yakymenko I, Tsybulin O, Sidorik E, Henshel D, Kyrylenko O, Kyrylenko S. Oxidative mechanisms of biological activity of low-intensity radiofrequency radiation. Electromagn Biol Med. 2016;35(2):186-202. https:// doi.org/10.3109/15368378.2015.1043557

30. Yang H, Zhang Y, Wang Z, Zhong S, Hu G, Zuo W. The effects of mobile phone radiofrequency radiation on cochlear stria marginal cells in Sprague-Dawley rats. Bioelectromagnetics. 2020;41(3):219-29. https:// doi.org/10.1002/bem.22255.

31. Gautam R, Singh KV, Nirala J, Murmu NN, Meena R, Rajamani P. Oxidative stress-mediated alterations on sperm parameters in male Wistar rats exposed to $3 \mathrm{G}$ mobile phone radiation. Andrologia. 2019;51(3):e13201. https://doi.org/10.1111/and.13201.

32. Carter CS, Huang SC, Searby CC, Cassaidy B, Miller MJ, Grzesik WJ, et al. Exposure to static magnetic and electric fields treats type 2 diabetes. Cell Metab. 2020;32(4):561-74. e7. https://doi.org/10.1016/j.cmet.2020. 09.012

33. Fragopoulou AF, Polyzos A, Papadopoulou MD, Sansone A, Manta AK, Balafas E, et al. Hippocampal lipidome and transcriptome profile alterations triggered by acute exposure of mice to GSM $1800 \mathrm{MH}$ z mobile phone radiation: an exploratory study. Brain Behavior. 2018;8(6):e01001. https://doi.org/10.1002/brb3.1001.

34. Perera PGT, Nguyen THP, Dekiwadia C, Wandiyanto JV, Sbarski I, Bazaka $\mathrm{O}$, et al. Exposure to high-frequency electromagnetic field triggers rapid uptake of large nanosphere clusters by pheochromocytoma cells. Int J Nanomed. 2018;13:8429. https://doi.org/10.2147/IJN.S1837 67.

35. Smith-Roe SL, Wyde ME, Stout MD, Winters JW, Hobbs CA, Shepard KG, et al. Evaluation of the genotoxicity of cell phone radiofrequency radiation in male and female rats and mice following subchronic exposure. Environ Mol Mutagen. 2020;61(2):276-90. https://doi.org/10.1002/em. 22343.

36. Alkis ME, Bilgin HM, Akpolat V, Dasdag S, Yegin K, Yavas MC, et al. Effect of 900-, 1800-, and 2100-MHz radiofrequency radiation on DNA and oxidative stress in brain. Electromagn Biol Med. 2019;38(1):32-47. https://doi.org/10.1080/15368378.2019.1567526.

37. Phillips JL, Singh NP, Lai H. Electromagnetic fields and DNA damage. Pathophysiology. 2009;16(2-3):79-88. https://doi.org/10.1016/j.patho phys.2008.11.005.

38. Sambad S, Wu SY, Jimenez H, Xing F, Zhu D, Liu Y, et al. Ca2+ and CAC$\mathrm{NA} 1 \mathrm{H}$ mediate targeted suppression of breast cancer brain metastasis by AM RF EMF. EBioMedicine. 2019;44:194-208. https://doi.org/10. 1016/j.ebiom.2019.05.038.

39. American National Standards Institute. Safety levels with respect to human exposure to radio frequency electromagnetic fields, $300 \mathrm{kHz}$ to 100GHz: American National Standards Institute; 1982. Available from: https://ehtrust.org/wp-content/uploads/2015/11/ANSI-National-stand ards-1982-safety-levels-for-human-exposure.pdf.

40. Institute of Electrical and Electronics Engineers. (Revision of ANSI C95.1-1982). IEEE standard for safety levels with respect to human exposure to radio frequency electromagnetic fields, $3 \mathrm{kHz}$ to $300 \mathrm{GHz}$. IEEE Std C95. 1991. https://doi.org/10.1109/IEEESTD.1992.101091. .

41. Vornoli A, Falcioni L, Mandrioli D, Bua L, Belpoggi F. The contribution of in vivo mammalian studies to the knowledge of adverse effects of radiofrequency radiation on human health. Int J Environ Res Public Health. 2019;16(18):3379. https://doi.org/10.3390/ijerph16183379.

42. Melnick RL. Commentary on the utility of the National Toxicology Program study on cell phone radiofrequency radiation data for assessing human health risks despite unfounded criticisms aimed at minimizing the findings of adverse health effects. Environ Res. 2019;168:1-6. https://doi.org/10.1016/j.envres.2018.09.010.

43. Belpoggi F, Falcioni L, Panzacchi S, Sgargi D, Mandrioli D. Response to "Cancerogenic effects of radiofrequency radiation: A statistical reappraisal" Environ Res. 2021;197:111067. https://doi.org/10.1016/j.envres. 2021.111067

44. National Toxicology Program. 595: NTP Technical Report on the Toxicology and Carcinogenesis Studies in Hsd: Sprague Dawley SD Rats Exposed to Whole-Body Radio Frequency Radiation at a Frequency ( $900 \mathrm{MHz}$ ) and Modulations (GSM and CDMA) Used by Cell Phones. National Toxicology Program, US Department of Health and Human Services. 2018. Available from: https://ntp.niehs.nih.gov/ntp/htdocs/lt_ rpts/tr595_508.pdf?utm_source=direct\&utm_medium=prod\&utm_ campaign=ntpgolinks\&utm_term $=\operatorname{tr} 595$.

45. National Toxicology Program. Technical report on the toxicology and carcinogenesis studies in B6c3f1/N mice exposed to Whole-Body radio frequency radiation at a frequency $(1,900 \mathrm{MHz})$ and modulations (GSM and (DMA) used by cell phones. Research Triangle Park, North Carolina; National Toxicology Program, National Institutes of Health. Public Health Service, US Department of Health and Human Services, NTP TR. 2018;596. Available from: https://ntp.niehs.nih.gov/ntp/htdocs/It_rpts/ tr596_508.pdf?utm_source=direct\&utm_medium=prod\&utm_campa ign=ntpgolinks\&utm_term $=\operatorname{tr} 596$.

46. National Toxicology Program. Cell Phone Radio Frequency Radiation. 2020. Available from: https://ntp.niehs.nih.gov/whatwestudy/topics/ cellphones/index.html.

47. U.S Environmental Protection Agency. Benchmark dose technical guidance. US Environmental Protection Agency. 2012. Available from: https://www.epa.gov/sites/production/files/2015-01/documents/ benchmark_dose_guidance.pdf.

48. EFSA Scientific Committee, Hardy A, Benford D, Halldorsson T, Jeger MJ, Knutsen $\mathrm{KH}$, et al. Update: use of the benchmark dose approach in risk assessment. EFSA J. 2017;15(1):e04658. https://doi.org/10.2903/j.efsa. 2017.4658

49. Haber LT, Dourson ML, Allen BC, Hertzberg RC, Parker A, Vincent MJ, et al. Benchmark dose (BMD) modeling: current practice, issues, and challenges. Crit Rev Toxicol. 2018;48(5):387-415. https://doi.org/10. 1080/10408444.2018.1430121.

50. California OEHHA. Air toxics hot spots risk assessment guidelines: Technical support document for the derivation of noncancer reference exposure levels. Sacramento: Office of Environmental Health Hazard Assessment, California Environmental Protection Agency; 2008. https:// oehha.ca.gov/media/downloads/crnr/noncancertsdfinal.pdf.

51. California OEHHA. Methodologies for derivation, listing of available values, and adjustments to allow for early life stage exposures. Technical Support Document for Cancer Potency Factors Appendix A: Hot Spots Unit Risk and Cancer Potency Values. 2009. Available from: https:// oehha.ca.gov/air/crnr/technical-support-document-cancer-potencyfactors-2009

52. Santini SJ, Cordone V, Falone S, Mijit M, Tatone C, Amicarelli F, et al. Role of mitochondria in the oxidative stress induced by electromagnetic fields: focus on reproductive systems. Oxidative Med Cellular Longevity. 2018;2018. https://doi.org/10.1155/2018/5076271.

53. Kim JH, Lee J-K, Kim H-G, Kim K-B, Kim HR. Possible effects of radiofrequency electromagnetic field exposure on central nerve system. Biomol Therapeut. 2019;27(3):265. https://doi.org/10.4062/biomolther. 2018.152.

54. Narayanan SN, Jetti R, Kesari KK, Kumar RS, Nayak SB, Bhat PG. Radiofrequency electromagnetic radiation-induced behavioral changes and their possible basis. Environ Sci Pollution Res. 2019:1-18. doi: https:// doi.org/10.1007/s11356-019-06278-5.

55. National Research Council. Science and decisions: advancing risk assessment: National Academies Press; 2009. Available from: https:// www.nap.edu/catalog/12209/science-and-decisions-advancing-riskassessment

56. Landrigan PJ, Kimmel CA, Correa A, Eskenazi B. Children's health and the environment: public health issues and challenges for risk assessment. Environ Health Perspect. 2004;112(2):257-65. https://doi.org/10. 1289/ehp.6115. 
57. Hardell L, Carlberg M, Mild KH. Epidemiological evidence for an association between use of wireless phones and tumor diseases. Pathophysiology. 2009;16(2-3):113-22. https://doi.org/10.1016/j.patho phys.2009.01.003.

58. Gong Y, Capstick MH, Kuehn S, Wilson PF, Ladbury JM, Koepke G, et al. Life-time dosimetric assessment for mice and rats exposed in reverberation chambers for the two-year NTP cancer bioassay study on cell phone radiation. IEEE Trans Electromagn Compat. 2017;59(6):1798-808. https://doi.org/10.1109/TEMC.2017.2665039.

59. Gandhi OP. Microwave emissions from cell phones exceed safety limits in Europe and the US when touching the body. IEEE Access. 2019;7:47050-2. https://doi.org/10.1109/ACCESS.2019.2906017.

60. Kuhne J, Schmidt JA, Geschwentner D, Pophof B, Ziegelberger G. Thermoregulatory stress as potential mediating factor in the ntp cell phone tumor study. Bioelectromagnetics. 2020;41(6):471. https://doi.org/10. 1002/bem.22284.

61. Melnick R. Regarding ICNIRP'S evaluation of the national toxicology program's carcinogenicity studies on radiofrequency electromagnetic fields. Health Phys. 2020;118(6):678-82. https://doi.org/10.1097/HP.0000000000 001268.

\section{Publisher's Note}

Springer Nature remains neutral with regard to jurisdictional claims in published maps and institutional affiliations.
Ready to submit your research? Choose BMC and benefit from:

- fast, convenient online submission

- thorough peer review by experienced researchers in your field

- rapid publication on acceptance

- support for research data, including large and complex data types

- gold Open Access which fosters wider collaboration and increased citations

- maximum visibility for your research: over 100M website views per year

At BMC, research is always in progress.

Learn more biomedcentral.com/submissions 